OPEN ACCESS

Edited by:

Gabriella Scarlatti,

San Raffaele Hospital

(IRCCS), Italy

Reviewed by:

Klaus Uberla,

Ruhr University Bochum,

Germany

George Kenneth Lewis,

Institute of Human

Virology (IHV),

United States

${ }^{*}$ Correspondence:

Christiane Moog

c.moog@unistra.fr

tThese authors have contributed equally to this work.

Specialty section:

This article was submitted

to HIV and AIDS,

a section of the journal

Frontiers in Immunology

Received: 31 August 2017 Accepted: 06 November 2017

Published: 20 November 2017

Citation:

Mayr LM, Su B and Moog C (2017) Non-Neutralizing Antibodies Directed against HIV and Their Functions.

Front. Immunol. 8:1590. doi: 10.3389/fimmu.2017.01590

\section{Non-Neutralizing Antibodies Directed against HIV and Their Functions}

\author{
Luzia M. Mayrit, Bin Su ${ }^{2 \dagger}$ and Christiane Moog ${ }^{1 *}$ \\ 'INSERM U1109, Fédération de Médecine Translationnelle de Strasbourg (FMTS), Université de Strasbourg, Strasbourg, \\ France, ${ }^{2}$ Beijing Key Laboratory for HIVIAIDS Research, Center for Infectious Diseases, Beijing You'an Hospital, Capital \\ Medical University, Beijing, China
}

B cells produce a plethora of anti-HIV antibodies (Abs) but only few of them exhibit neutralizing activity. This was long considered a profound limitation for the enforcement of humoral immune responses against HIV-1 infection, especially since these neutralizing Abs (nAbs) are extremely difficult to induce. However, increasing evidence shows that additional non-neutralizing Abs play a significant role in decreasing the viral load, leading to partial and sometimes even total protection. Mechanisms suspected to participate in protection are numerous. They involve the Fc domain of Abs as well as their Fab part, and consequently the induced $A b$ isotype will be determinant for their functions, as well as the quantity and quality of the Fc-receptors (FcRs) expressed on immune cells. Fc-mediated inhibitory functions, such as Ab-dependent cellular cytotoxicity, antibody-dependent cellular phagocytosis, aggregation, and even immune activation have been proposed. However, as for nAbs, the non-neutralizing activities are limited to a subset of anti-HIV Abs. An improved in-depth characterization of the Abs displaying these functional responses is required for the development of new vaccination strategies, which aim to selectively trigger the $B$ cells able to induce the right functional $\mathrm{Ab}$ combinations both at the right place and at the right time. This review summarizes our current knowledge on non-neutralizing functional inhibitory Abs and discusses the potential benefit of inducing them via vaccination. We also provide new insight into the roles of the FcyR-mediated Ab therapeutics in clinical trials for HIV diseases.

Keywords: HIV-1 infection, non-neutralizing antibodies, antibody functions, antibody-dependent cellular cytotoxicity, Fc-receptor-mediated inhibition

\section{INTRODUCTION}

A strong antibody $(\mathrm{Ab})$ response is mounted following HIV infection but most Abs targeting the HIV have little neutralizing capacity. Upon humoral immune activation via infection, B cells undergo somatic hypermutations and isotype switching of the immunoglobulin gene in order to enhance the efficacy of the Ab response against the specific antigen (1). B cells can then differentiate into long-lived plasma cells (2). However, most of the B cells induced are directed against decoyed immune-dominant epitopes that have no or low antiviral function. The targeted epitopes are either useless for antiviral activity (directed against unfolded glycoprotein that are not present on infectious viruses) or against epitopes able to efficiently and quickly mutate to escape from the immune response. Only $10-20 \%$ of infected individuals are able to mount a B-cell response leading to the production of broadly neutralizing Abs (bnAbs). These bnAbs represent, therefore, only a minor 
amount of the humoral $\mathrm{Ab}$ response induced following HIV infection. They have specific characteristics: they are produced from B cells that undergo unusually long maturation steps with extraordinary levels of somatic mutations compared to germline and display long heavy chain complementarity-determining regions 3 to be able to bind masked epitopes. This allows the development of Abs that target specific antigens with high affinity (2).

In addition to germline mutation, the consecutive immunoglobulin class switching will change the Ab isotype (3). This Ab isotype switch is also determinant for its gain of function. The heavy chain constant region determining the Ab isotype will not only impact the neutralization capacity (via the Fab domain) but also play a crucial role on the Ab effector functions (via the Fc domain). In fact, the heavy chains define the Fc domain that will directly modulate the Fc-mediated inhibitory functions. These functions will greatly influence the further immune response. Interestingly, Fc-mediated inhibitory function was detected not only on neutralizing Abs (nAbs) but also on some specific Abs lacking neutralizing activity, therefore, called non-neutralizing inhibitory Abs (4) [reviewed in Ref. (5-11)].

In vivo, the Fc-mediated functions are now being addressed. It is well documented that the Fc-mediated effector functions contribute to Ab-mediated protection against HIV-1 for bnAbs $(5-8,12,13)$. Two recent studies have tracked virus replication after early experimental mucosal infection and passive protective bnAb therapy $(14,15)$. Liu et al. showed that, in animals pretreated with bnAb PGT121 1 day before challenge with high-dose mucosal SHIV, early viral foci are detected at the distal site of infection before complete virus clearance (14). These results showed that bnAbs are able to eliminate the infected cells if some virus escapes from the neutralization of infection. Moreover, Hessell et al. found that early short-term post-exposure treatment with a cocktail of bnAbs VRC07-523 and PGT121 in newborn macaques, 1 day after oral $\mathrm{SHIV}_{\mathrm{SF} 162 \mathrm{P} 3}$ challenge can intercept replicating viral foci established by day 1 (15). This study demonstrates that passive immunotherapy by $\mathrm{Ab}$ can eliminate viral foci and thereby prevent the establishment of viral reservoirs $(14,15)$. These two studies exploring early virus replication in the presence of nAbs clearly demonstrate that HIV escaping from neutralization can infect cells at a distal site of virus inoculation and be subsequently eliminated by bnAbs. They reveal that the complete lack of infection is not mandatory to obtain protection by nAbs. The discovery that nAbs can eliminate a few foci of infected cells is extremely useful for the vaccine field as this type of activity cannot be referred to as neutralization. The mechanism by which Abs ensure clearance of infected cells is not known but obviously these additional observations reinforce the potential role of Fc-mediated functions in the protective mechanisms of bnAbs. These results open a complete new area of research for the development of protective $\mathrm{Ab}$ responses. Additional experiments are now required to define the mechanism of infected cell clearance. In particular, increased analysis of the Ab protection at very early time points following challenge will help to identify the multiple inhibitory functions displayed by bnAbs.

The role of Fc-mediated functions of Abs lacking the broadly neutralizing capacity in HIV protection is still a matter of debate. Importantly, specific Fc-mediated functions of nonneutralizing Abs (non-nAbs) are the only correlates of protection against infection observed in the RV144 vaccine trial conducted in Thailand (16-19). Still, how non-nAbs have contributed to protection remains unclear. In the non-human macaque model, the non-nAbs have shown some trends of decreased viral load or decreased number of transmitted founder viruses $(20,21)$. The exact mechanisms leading to this lower infection rate is not known, but again indicated that non-nAbs may participate in protection. Active immunization with HIV-1 vaccine candidates suggests that weakly neutralizing or non-nAbs protect by using Fc-mediated effector functions, albeit with a much lower dynamic range as for passive immunization with bnAbs (22). New tools, such as knockout mice or Abs engineered to abrogate or enhance certain functions, were recently developed. These technologies recently paved way for the demonstration of the role of Fc-mediated functions (23). Treatment with a non$\mathrm{nAb}$ directed against the principal immunodominant domain of gp41 allowed for the selection of a recurring HIV mutation within the CD4 binding site in a totally Fc-dependent manner (23). These data are consistent with the hypothesis that a high titer polyclonal anti-envelope (env) non-nAb response may be sufficient to reach low levels of protection against HIV. Future directions need to more precisely characterize the functions and $\mathrm{Ab}$ characteristics needed to achieve such protection.

The identification of these additional non-neutralizing inhibitory Abs opens a whole new area of research. Functions involving the Fc domain of Abs can occur simultaneously, sequentially, and can sometimes be conflicting with other Ab functions. They were shown to contribute to the overall protective effect of Abs and to an efficient humoral immune response $(5,8-10,12,13,20$, 21, 23-25). This review will discuss the opportunity, difficulties, limitations, and parameters influencing these $\mathrm{Fc}$-mediated $\mathrm{Ab}$ functions.

\section{FUNCTIONAL ACTIVITIES OF AbS CAPTURING INFECTIOUS HIV PARTICLES}

HIV-specific Abs are directed against numerous epitopes of the HIV glycoprotein, but only few are accessible as a quaternary structure of the functional trimeric envelope. Among them, five hotspot epitopes were shown to be involved in HIV neutralization $(26,27)$. Even so, Abs to additional epitopes were shown to bind to infectious viruses either by targeting additional epitopes on the trimeric env or non-functional env spikes expressed on HIV particles. These additional Abs, although not neutralizing, are able to bind and capture infectious virus, form immune complexes and/or virus/ $\mathrm{Ab}$ aggregates, therefore leading to additional inhibitory functions.

\section{HIV INHIBITION BY AGGREGATION}

Formation of virus aggregates is a very basic mechanism of inhibition leading to the decrease of virus infectivity (28-32). The aggregates are formed by a network of $\mathrm{Ab} /$ virus interactions, where the virus is trapped. This leads to virus inactivation by 
limiting the distribution and accessibility of available pathogens, decreasing their motility or disrupting their integrity. This mechanism applies to Abs binding to numerous epitopes exposed at the surface of the virus particle. Aggregation more likely occurs with polymeric IgA that are able to dimerize via their Fc domain and IgM displaying pentameric forms. Indeed, inhibition by aggregation was proposed for the exceptional protective effect observed with IgA1 (33). In this study, a correlation was observed between the binding capacity of the anti-HIV IgA1 subclass Abs and the protective effect on rectal experimental challenge (33). For IgG, aggregation occurs by the recognition of two distinct epitopes/virions entities. This activity, therefore, usually has a dome-shaped relationship to the $\mathrm{Ab}$ concentration, declining at higher occupancies when it becomes improbable that a free paratope of an $\mathrm{Ab}$ molecule already bound to one virion can find a free epitope on a second virion. In the female reproductive tract containing cervical mucus, HIV aggregates will be trapped more efficiently as free virus particles (34). Moreover, the immune complexes formed may be retained efficiently in the mucus by their binding to MUC16 via the Fc domain of IgG Abs (24). In addition to this mechanic inhibition of HIV by aggregate formation, more complex mechanisms involving a further binding of the Abs to the Fc-receptor ( $F c R$ ) expressed on the surface may take place.

\section{THE ROLE OF FcRs}

Fc-mediated inhibitory activity is entirely dependent on the capacity of Abs to trigger FcRs. These FcRs have to interact with the Fc domain of the Abs to trigger the Fc-mediated functions. Based on their homology, three classes of FcyRs have been described (FcyRI, II, and III). The distinct family members, including Fc $\gamma$ RI, Fc $\gamma$ RIIa, Fc $\gamma$ RIIb, Fc $\gamma$ RIIIa, and Fc $\gamma$ RIIIb, are differentially expressed on the surface of immune cells, such as B cells, dendritic cells (DCs), NK cells, macrophages, neutrophils, eosinophils, and basophiles (35-39). They differ in their $\mathrm{Ab}$ affinities, favoring certain IgG subtypes depending on their amino acid sequences. This differential binding capacity, depending on the $\mathrm{Ab}$ isotype and the $\mathrm{FcR}$ genotype and its expression on the cell modulates the $\mathrm{Ab}$ activities and their capacity to activate or inhibit FcR-expressing cells. Therefore, the different FcR polymorphisms of the host need to be taken into consideration when analyzing FcR-mediated functions of Abs.

Single-nucleotide polymorphisms (SNPs) have been described to occur in FcyRIIa, FcyRIIIa, and FcyRIIb at protein positions 131, 158, and 232, respectively, while human Fc $\gamma$ RI was not found to be polymorphic. Since these SNPs affect FcR expression and IgG isotype binding leading to distinct effector functions, they can influence HIV vaccine efficacy, infection risk, and disease progression. For example, specific polymorphisms at the Fc $\gamma$ RIIa (change from $\mathrm{H}$ to $\mathrm{R}$ at position 131) and the FcyRIIIa (change from $\mathrm{V}$ to $\mathrm{F}$ at position 158) gene loci have been associated with an HIV vaccine benefit (40). Li et al. described that subjects carrying a SNP in FcyRIIc (126C $>\mathrm{T})$ were associated with a significant prevention of infection with an AE HIV-1 strain in the RV144 vaccine clinical trial (41). On the contrary, a small study that compared the FcyRIIa and FcyRIIIa genotype profiles of 73 patients that were able to control HIV with progressor patients did not find any difference in genotype frequency (42). The role of the different FcR polymorphisms and how it will impact on the overall HIV immune response is not known. Therefore, future research will need to assess in more details the role of FcR polymorphisms of the host on HIV infection and HIV vaccine development.

\section{ANTIBODY-DEPENDENT CELLULAR PHAGOCYTOSIS (ADCP)}

Antibody-dependent cellular phagocytosis, which relies on phagocytes to internalize and degrade Ab-opsonized pathogens, is a well-described immune process. Abs coated to pathogens via their Fab domain will bind with their Fc domain to the FcR expressed on monocytes, macrophages, and neutrophils to increase rapid elimination of the microorganisms. In the case of HIV, phagocytosis of immune complexes via the Fc domain of the nAbs was found to be associated with protective activity in the macaque model (43-45) and, recently, phagocytosis by macrophages or activated neutrophils was proposed to play a significant role in human tissues, even though it is yet unknown how exactly this inhibition occurs (46). Interestingly, this activity was also described for non-nAbs able to form immune complexes. It was shown that for some HIV-specific Abs, the binding via the Fab domain, on the one hand, and the binding to an antigenpresenting cell (APC) via the Fc domain, on the other hand, leads to efficient inhibition of HIV replication of the APCs (4). Phagocytosis by cell lines was shown using different HIV-specific Abs and gp120-coated beads (47) and when these cell lines were engineered to express different FcRs, the FcR-mediated inhibitory function of Abs was partially recovered. This type of activity relies on multiple Abs, able to form immune complexes and especially for Abs directed to the HIV gp41 epitope (33). Although HIV inhibition by phagocytosis of the immune complex could not be demonstrated using this FcR-expressing cell line, it was proposed that immune complex binding of Fc $\gamma$ RI provides a kinetic advantage for gp41 nAbs against partially cryptic epitopes (33). An alternative mechanism may be proposed based on the observation that virus co-localizes with Abs and FcRs at the surface of APCs for a prolonged period. In this case, HIV captured at the cell surface $v i a$ FcRs is deviated from the infection process, which requires binding to receptor/co-receptor for fusion with the cell membrane.

\section{IMMUNOLOGICAL Ab FUNCTION}

Antigen-presenting cells are specialized cells devoted to phagocyte immune complexes via their FcRs. This phagocytic process is much more efficient than the direct phagocytosis of pathogen by endocytosis. This mechanism of Fc-mediated phagocytosis of immune complexes will lead to an optimized induction of the adaptive immune response by APCs. In this regard, Abs forming the immune complexes may directly participate in the induction of the adaptive immune responses required for prolonged protection. The contribution of Abs in the development of an adaptive 
immune response was first described in the cancer field (48). Abs targeting tumor antigens were shown to interact with immune cells through Fc-dependent mechanisms to induce adaptive immune responses (49-51).

Increasing body of evidence suggests that this mechanism may also apply following HIV infection. Noteworthy, in vitro, the presence of $\mathrm{HIV} / \mathrm{Ab}$ immune complexes induces the maturation of human DCs, supporting immune activation (52-54). The stimulation of the adaptive immune response was also observed following $\mathrm{nAb}$ therapy in infected macaques $(45,55)$. An increase of specific B-cell responses following passive $\mathrm{nAb}$ transfer in a non-human primate (NHP) model was described by Haigwoog's team (56). The immune complexes were able to activate T-cell immunity (57). More recently, human clinical data described the elicitation of host humoral responses in viremic subjects after a single injection of the potent anti-HIV nAb 3BNC117 (58). 3BNC117 immunotherapy was found to accelerate the level of neutralization breadth. Overall, these studies attribute an "immunogenic" role to Abs in that they may be able to induce primary and memory responses more efficiently than free viral particles or infected cells. Accordingly, Abs without neutralizing potency but able to form immune complexes may also lead to immune activation. Further investigations will be necessary to characterize the Abs involved in the implementation of an adaptive antiviral response, paving the way to new fields of applications.

\section{FcR-MEDIATED INHIBITION OF CELL-TO-CELL HIV-1 TRANSMISSION}

Noteworthy, APCs have been described as "Trojan horses" that, in addition to their capacity to mount an efficient immune response, will also facilitate the spread of HIV by efficient HIV transmission and dissemination to the surrounding CD4 $\mathrm{T}$ lymphocytes. Indeed, spread of HIV-1 infection through direct cell-to-cell HIV-1 transmission has been shown to be 100- to 1,000 -fold more efficient than infection by cell-free virus, making a large and efficient contribution to HIV propagation and dissemination through the body $(10,59-61)$. Therefore, preventing cell-to-cell transmission of HIV-1 by specific Abs is crucial for inhibiting HIV-1 propagation. However, most in vitro neutralization assays and in vivo $\mathrm{nAb}$ protection experiments have been performed by using cell-free virus.

Studies analyzing the inhibition of cell-to-cell HIV-1 transmission by $\mathrm{nAbs}$ used diverse models of HIV-1 transmission, with different donor and target cells, various viral strains, and $\mathrm{Ab}$ and different readout for cell-to-cell transmission. Consequently, the results are divergent and controversial, some studied showing decreased $\mathrm{Ab}$ potential when HIV is directly transmitted to a target cell compared to inhibition of cell-free virus (62-72), whereas other studies showing similar inhibitory potential for cell-free versus cell-to-cell transmission (52-54, 73). Noteworthy, in comparative studies where the experimental design is normalized for the same replication capacity between cell-free or cellassociated virus and where the same primary target cells were used, identical Ab inhibitory activities were observed $(52-54,74)$. Under these conditions, cell-to-cell HIV-1 transmission from
DCs/macrophages to CD4 T cells was inhibited to a similar extent as cell-free virus particles. Interestingly, similar results were described for antiviral compounds after normalization for virus replication and target cells $(73,75)$. These findings highlight the potential role of bnAb in protection from early HIV-1 transmission and rapid dissemination at mucosal frontlines if locally present early after sexual transmission.

As HIV-1 Abs can bind FcRs, Abs may inhibit HIV-1 transmission via FcR-mediated inhibitory activity. It was shown that nonneutralizing inhibitory Abs such as 246-D do not directly affect HIV-1 transmission from infected DCs to autologous CD4 T cells (54). Therefore, non-neutralizing inhibitory Abs were proposed to have no direct effect on HIV transmission. However, such Abs were shown to significantly reduce the percentage of infected DCs in DC-T cell co-cultures (54). For these non-neutralizing inhibitory Abs, a strong association was found between the Fc $\gamma$ Rspecific binding capacity, the inhibition of $\mathrm{HIV}-1$ replication and the DC maturation. This suggests that the binding of these Abs to DCs triggers the maturation of these cells, resulting in lower levels of R5 virus replication $(10,54)$. Moreover, IgG-opsonized HIV-1 has been showed to impair provirus formation, p24 production and to decrease the long-term transmission rate to autologous non-stimulated CD4 T cells (76). These unconventional mechanisms of HIV inhibition detected in DCs but not in CD4 T lymphocytes may explain the lower levels of infection in the co-culture in the presence of non-nAbs. Therefore, these Fc-mediated inhibitory activities of Abs in DCs may participate in the overall diminution of HIV replication in DC-T cell HIV-1 transmission.

Altogether, the multiple $\mathrm{Ab}$ inhibitory activities should be taken into consideration for the study of the inhibition of cellto-cell HIV-1 transmission. A better understanding of this FcRmediated inhibition of HIV transmission is needed for future Ab-based therapeutics and protection strategies.

\section{ANTIBODY-DEPENDENT CELLULAR CYTOTOXICITY (ADCC)}

Antibody-dependent cellular cytotoxicity, a complex and potent Fc-mediated effector function, requires the linking of an HIVinfected target cell to an immune effector cell via HIV-specific Abs. In this regard, Abs have to bind to HIV env, which is expressed on the surface of infected cells, via their Fab part and use their Fc domain to interact with FcRs expressed on the surface of effector cells, such as NK cells. This double interaction triggers the release of cytotoxic granules containing perforin and granzymes from the effector cells, leading to the death of the Ab-bound infected target cells.

Antibody-dependent cellular cytotoxicity as well as nonneutralizing anti-V1/V2 Ab induction was shown to correlate with reduced HIV-1 infection risk in the human vaccine trial RV144 and in several NHPs studies $(16,18,77-79)$. The data strongly suggest for ADCC to be a significant mechanism of protection against HIV-1 in vivo $(7,10,22,80)$. Interestingly, non-neutralizing anti-V2 monoclonal Abs elicited in HIV-1infected patients recently showed strong cross-reactive ADCC 
activity using different primary subtype $\mathrm{B}$ and $\mathrm{C}$ isolates as well as subtype B Transmitted/Founder viruses in vitro (81). This study reinforces the potential role of V2-specific Abs. However, as ADCC is a complex and multilayered activity, questions remain about which ADCC assay best reflects the biology of protection and shows the best correlation with in vivo studies. In vitro assays are difficult to carry out and the variability obtained between different ADCC assays developed in the HIV field is alarmingly high, due to different assay formats and readouts circulating in the field.

As the HIV env is conformationally highly dynamic and as different epitopes are exposed during the different phases of infection because of structural rearrangements, the window of opportunity for Abs to bind to their specific epitope in order to mediate ADCC might only be a few hours, during the viral entry and budding phases $(7,8,82)$. Furthermore, different env forms (such as intact env, non-trimeric env, gp41 stumps, env peptides presented by the MHC, and so on) are expressed on infected cells depending on the Nef and Vpu accessory proteins present in the chosen virus type (primary virus, pseudovirus, infectious molecular clone). Also, HIV was shown to prevent the accumulation of env at the surface of target cells via a Vpu-mediated BST-2 antagonism (83). Noteworthy, the epitopes tackled by Abs with potential ADCC functions may differ from that involved in neutralization, opening the possibility of additional, enlarged, and distinct pattern of functional Abs. As a result, depending on the different env conformations, the recognition of specific epitopes will be influenced and have an impact on the ADCC results (84).

As ADCC relies on the capacity of the Ab to target infected cells, it could be proposed that by extension, Abs directed to all type of markers specifically expressed on infected cells may make the job. Therefore, targeting infected cells with Abs directed to FcRIIa, a marker recently identified on HIV cells reservoirs (85) or to specific markers of cell stress induced following infection (as NKG2D or MHC-E) may also participate in infected cell clearance. Another factor influencing ADCC outcomes and, thus, HIV disease progression are the target cells that carry out the lysis, which are predominantly NK cells. Their maturation and activation status as well as their subset distribution can vary widely in different tissues and according to the individual. Therefore, the activation of the ADCC target cells may be envisaged to enhance ADCC efficiency. Also, different polymorphisms on FcyRIIIa, expressed on NK cells, can impact their activation and ADCC activity (86).

\section{ANTIBODY-MEDIATED COMPLEMENT ACTIVATION}

The complement system is an integral part of the innate immune system which has multiple effects, including opsonization, recruitment of inflammatory cells, and cell lysis/virolysis. Complement activation can occur through three distinct pathways: classical, alternative, and lectin, and is vital for both innate and adaptive immune responses (87-91). Complement activation results in the generation of C3 and C5 convertase complexes, which cleave $\mathrm{C} 3$ and $\mathrm{C} 5$, respectively, to generate the anaphylatoxin components $\mathrm{C} 3 \mathrm{a}$ and $\mathrm{C} 5 \mathrm{a}$ as well as the opsonin $\mathrm{C} 3 \mathrm{~b}$, membrane attack complexes initiator $\mathrm{C} 5 \mathrm{~b}$ and, finally, to perforate the viral surface causing disruption and, thus, complement-mediated lysis $(87,88,91)$.

Antibody-mediated complement activation by HIV has been widely studied over the years. The initially published studies on complement and HIV were conflicting $(92,93)$. Some reports said that the virus did not bind human serum complement unless $\mathrm{Ab}$ to the virus was present. Others suggested that the virus activated and bound complement spontaneously, even in the absence of Ab. The current knowledge, however, concludes that HIV has developed a sophisticated defense that protects the virus by failing to bind complement proteins. Indeed, virions bind complement poorly (especially the gp120 that is refractory to complement binding) (94). Moreover, HIV incorporates the human cell membrane complement down-regulatory molecules CD46, CD55, and CD59 during budding, thereby inhibiting complement-mediated damage to the virus. For this reason, the use of primary isolates produced by primary cells is absolutely mandatory for the study of complement-mediated effects. HIV also captures serum factor $\mathrm{H}$ to downregulate complement binding (95-97). On the other hand, HIV has evolved several mechanisms to exploit the complement system to facilitate the binding of HIV to target cells via CR2 or CD21 proteins, therefore leading to the enhancement of viral infectivity and the formation of virus reservoirs at different stages (98-104). For example, complement-mediated enhancement of HIV-1 by autologous non-nAbs obtained during acute HIV-1 infection was recently illustrated in in vitro studies $(95,98)$.

Interestingly, the role of complement activity of the Fc domain of $\mathrm{nAb}$ b12 evaluated in the non-human macaque challenge model revealed that a b12 Fc mutant defective for C1q binding and complement activation exhibited comparable activity to that of wild-type b12 (13). This indicates that complement is not required for optimal in vivo $\mathrm{Ab}$ protection against SHIV infection (13). Nonetheless, complement activation by V1V2-specific Abs was stronger and detected more frequently in RV144 with a reduced risk of HIV-1 infection than in two related trials, VAX003 and VAX004, for which no significant protection was observed (105). These results suggest that a certain level of Ab-dependent complement activity may have contributed in part to a modest protection against the acquisition of HIV-1 infection in the phase III RV144 HIV-1 vaccine trial. Together, complement can mediate a variety of biological functions, the relative contribution of virus lysis and enhancement in the tissue and in the periphery may differ and needs to be further investigated. Additional studies will be needed to define the role of complement activation and regulation in HIV infection and to unravel whether the beneficial or the detrimental effects of complement and $\mathrm{Ab}$ dominate in vivo. A possible balance of $\mathrm{Ab}$-mediated immune responses, including complement activation, may be the key for the induction of in vivo protection against HIV.

\section{CONCLUSION}

The plethora of additional $\mathrm{Ab}$ functions listed below demonstrates the extremely large potential of functional Abs. 
Therefore, there is no single mechanism or assay that has come to the front to predict vaccine efficacy. This is a major issue confronting researchers in the HIV field and it is also important for other cases of Ab-mediated protection against infectious diseases.

The Abs will be produced by B cell following an interplay of somatic hypermutations and isotype switching. The successive modifications leading to the maturation of the immune response is still poorly understand. Recently, the frequency of HIV-envspecific memory B cells correlated positively with the neutralization breadth in HLA-B ${ }^{\star} 57+$ HIV elite controllers but not in HLA-B ${ }^{\star} 57$-elite controllers (ECs), suggesting a very specific induction or preservation of HIV-specific memory B cells in these patients (106). However, the factors allowing the establishment of this efficient humoral response is not known.

The long-lasting persistence of HIV following infection demonstrated that the sole repetitive contact with an antigen is not sufficient to mount a humoral response able to generate functional Abs. What are the additional component necessary to induce the rearrangement necessary to obtain B cells producing Abs with the Fab domain that recognize the right epitope and the Fc domain with the best functionality? Even more enigmatic, which immunization protocol can trigger such a response? The

\section{REFERENCES}

1. Haynes BF, Mascola JR. The quest for an antibody-based HIV vaccine. Immunol Rev (2017) 275:5-10. doi:10.1111/imr.12517

2. Moir S, Fauci AS. B-cell responses to HIV infection. Immunol Rev (2017) 275:33-48. doi:10.1111/imr.12502

3. den Haan JM, Arens R, van Zelm MC. The activation of the adaptive immune system: cross-talk between antigen-presenting cells, T cells and B cells. Immunol Lett (2014) 162:103-12. doi:10.1016/j.imlet.2014.10.011

4. Holl V, Peressin M, Decoville T, Schmidt S, Zolla-Pazner S, Aubertin AM, et al. Nonneutralizing antibodies are able to inhibit human immunodeficiency virus type 1 replication in macrophages and immature dendritic cells. J Virol (2006) 80:6177-81. doi:10.1128/JVI.02625-05

5. Mayr L, Su B, Moog C. Role of nonneutralizing antibodies in vaccines and/or HIV infected individuals. Curr Opin HIV AIDS (2017) 12:209-15. doi:10.1097/COH.0000000000000357

6. Bournazos S, Ravetch JV. Anti-retroviral antibody FcgammaR-mediated effector functions. Immunol Rev (2017) 275:285-95. doi:10.1146/ annurev-immunol-051116-052433

7. Lewis GK, Pazgier M, Evans DT, Ferrari G, Bournazos S, Parsons MS, et al. Beyond viral neutralization. AIDS Res Hum Retroviruses (2017) 33:760-4. doi:10.1089/AID.2016.0299

8. Lewis GK, Pazgier M, DeVico AL. Survivors remorse: antibody-mediated protection against HIV-1. Immunol Rev (2017) 275:271-84. doi:10.1111/ imr. 12510

9. French MA, Tjiam MC, Abudulai LN, Fernandez S. Antiviral functions of human immunodeficiency virus type 1 (HIV-1)-specific IgG antibodies: effects of antiretroviral therapy and implications for therapeutic HIV-1 vaccine design. Front Immunol (2017) 8:780. doi:10.3389/fimmu.2017.00780

10. Su B, Moog C. Which antibody functions are important for an HIV vaccine? Front Immunol (2014) 5:289. doi:10.3389/fimmu.2014.00289

11. Holl V, Peressin M, Moog C. Antibody-mediated Fcgamma receptor-based mechanisms of HIV inhibition: recent findings and new vaccination strategies. Viruses (2009) 1:1265-94. doi:10.3390/v1031265

12. Klein K, Veazey RS, Warrier R, Hraber P, Doyle-Meyers LA, Buffa V, et al. Neutralizing IgG at the portal of infection mediates protection against vaginal simian/human immunodeficiency virus challenge. J Virol (2013) 87:11604-16. doi:10.1128/JVI.01361-13 in-depth characterization of the different $\mathrm{Ab}$ functionality is the first step toward the understanding on how to trigger such an efficient B-cell response.

\section{AUTHOR CONTRIBUTIONS}

LM, BS, and CM wrote the manuscript. CM revised the manuscript.

\section{FUNDING}

We thank our financial supports, the French Agency for Research on AIDS and Viral Hepatitis (ANRS), the Vaccine Research institute, Investissements d'Avenir program managed by the ANR under reference ANR-10-LABX-77, SIDACTION Pierre Bergé, the European Union's Horizon 2020 research and innovation programme under grant agreement No. 681032, and the National Natural Science Foundation of China (81772165), the Funding for Chinese overseas talents returning to China in 2016 (BS), the Basic-Clinical Research Cooperation Fund of Capital Medical University (17JL20), Fund of Key Laboratory of Capital Medical University (2-03-02-BJYAH2016003), and the Beijing Key Laboratory for HIV/AIDS Research (BZ0089).

13. Hessell AJ, Hangartner L, Hunter M, Havenith CE, Beurskens FJ Bakker JM, et al. Fc receptor but not complement binding is important in antibody protection against HIV. Nature (2007) 449:101-4. doi:10.1038/ nature06106

14. Liu J, Ghneim K, Sok D, Bosche WJ, Li Y, Chipriano E, et al. Antibodymediated protection against SHIV challenge includes systemic clearance of distal virus. Science (2016) 353:1045-9. doi:10.1126/science.aag0491

15. Hessell AJ, Jaworski JP, Epson E, Matsuda K, Pandey S, Kahl C, et al. Early short-term treatment with neutralizing human monoclonal antibodies halts SHIV infection in infant macaques. Nat Med (2016) 22:362-8. doi:10.1038/ nm.4063

16. Zolla-Pazner S, deCamp A, Gilbert PB, Williams C, Yates NL, Williams WT, et al. Vaccine-induced IgG antibodies to V1V2 regions of multiple HIV-1 subtypes correlate with decreased risk of HIV-1 infection. PLoS One (2014) 9:e87572. doi:10.1371/journal.pone.0087572

17. Tomaras GD, Ferrari G, Shen X, Alam SM, Liao HX, Pollara J, et al. Vaccineinduced plasma IgA specific for the $\mathrm{C} 1$ region of the HIV-1 envelope blocks binding and effector function of IgG. Proc Natl Acad Sci U S A (2013) 110:9019-24. doi:10.1073/pnas.1301456110

18. Haynes BF, Gilbert PB, McElrath MJ, Zolla-Pazner S, Tomaras GD, Alam SM, et al. Immune-correlates analysis of an $\mathrm{HIV}-1$ vaccine efficacy trial. $N$ Engl J Med (2012) 366:1275-86. doi:10.1056/NEJMoa1113425

19. Bonsignori M, Pollara J, Moody MA, Alpert MD, Chen X, Hwang KK, et al. Antibody-dependent cellular cytotoxicity-mediating antibodies from an HIV-1 vaccine efficacy trial target multiple epitopes and preferentially use the VH1 gene family. J Virol (2012) 86:11521-32. doi:10.1128/JVI.01023-12

20. Santra S, Tomaras GD, Warrier R, Nicely NI, Liao HX, Pollara J, et al. Human non-neutralizing HIV-1 envelope monoclonal antibodies limit the number of founder viruses during SHIV mucosal infection in rhesus macaques. PLoS Pathog (2015) 11:e1005042. doi:10.1371/journal.ppat.1005042

21. Moog C, Dereuddre-Bosquet N, Teillaud JL, Biedma ME, Holl V, Van Ham G, et al. Protective effect of vaginal application of neutralizing and nonneutralizing inhibitory antibodies against vaginal SHIV challenge in macaques. Mucosal Immunol (2014) 7:46-56. doi:10.1038/mi.2013.23

22. Lewis GK, Finzi A, DeVico AL, Pazgier M. Conformational masking and receptor-dependent unmasking of highly conserved Env epitopes recognized by non-neutralizing antibodies that mediate potent ADCC against HIV-1. Viruses (2015) 7:5115-32. doi:10.3390/v7092856 
23. Horwitz JA, Bar-On Y, Lu CL, Fera D, Lockhart AAK, Lorenzi JCC, et al. Non-neutralizing antibodies alter the course of HIV-1 infection in vivo. Cell (2017) 170:637-648.e610. doi:10.1016/j.cell.2017.06.048

24. Gunn BM, Schneider JR, Shansab M, Bastian AR, Fahrbach KM, Smith A IV, et al. Enhanced binding of antibodies generated during chronic HIV infection to mucus component MUC16. Mucosal Immunol (2016) 9:1549-58. doi:10.1038/mi.2016.8

25. DiLillo DJ, Palese P, Wilson PC, Ravetch JV. Broadly neutralizing antiinfluenza antibodies require $\mathrm{Fc}$ receptor engagement for in vivo protection. J Clin Invest (2016) 126:605-10. doi:10.1172/JCI84428

26. McCoy LE, Burton DR. Identification and specificity of broadly neutralizing antibodies against HIV. Immunol Rev (2017) 275:11-20. doi:10.1111/ imr. 12484

27. Kwong PD, Chuang GY, DeKosky BJ, Gindin T, Georgiev IS, Lemmin T, et al. Antibodyomics: bioinformatics technologies for understanding B-cell immunity to HIV-1. Immunol Rev (2017) 275:108-28. doi:10.1111/imr.12480

28. Alexander MR, Sanders RW, Moore JP, Klasse PJ. Short communication: virion aggregation by neutralizing and nonneutralizing antibodies to the HIV-1 envelope glycoprotein. AIDS Res Hum Retroviruses (2015) 31:1160-5. doi:10.1089/AID.2015.0050

29. Stieh DJ, King DF, Klein K, Liu P, Shen X, Hwang KK, et al. Aggregate complexes of HIV-1 induced by multimeric antibodies. Retrovirology (2014) 11:78. doi:10.1186/s12977-014-0078-8

30. Watkins JD, Sholukh AM, Mukhtar MM, Siddappa NB, Lakhashe SK, Kim M, et al. Anti-HIV IgA isotypes: differential virion capture and inhibition of transcytosis are linked to prevention of mucosal R5 SHIV transmission. AIDS (2013) 27:F13-20. doi:10.1097/QAD.0b013e328360eac6

31. Stieh D, Gioia C, McRaven M, Cianci G, Kiser P, Hope T. Development of an imaging based virus aggregation assay for vaccine development. Retrovirology (2012) 9:319. doi:10.1186/1742-4690-9-S2-P319

32. Klasse PJ, Sattentau QJ. Occupancy and mechanism in antibody-mediated neutralization of animal viruses. JGen Virol (2002) 83:2091-108. doi:10.1099/0022-1317-83-9-2091

33. Perez LG, Costa MR, Todd CA, Haynes BF, Montefiori DC. Utilization of immunoglobulin G Fc receptors by human immunodeficiency virus type 1: a specific role for antibodies against the membrane-proximal external region of gp41. J Virol (2009) 83:7397-410. doi:10.1128/JVI.00656-09

34. Fahrbach KM, Malykhina O, Stieh DJ, Hope TJ. Differential binding of IgG and IgA to mucus of the female reproductive tract. PLoS One (2013) 8:e76176. doi:10.1371/journal.pone.0076176

35. Bournazos S, Ravetch JV. Fcgamma receptor function and the design of vaccination strategies. Immunity (2017) 47:224-33. doi:10.1016/j. immuni.2017.07.009

36. Boesch AW, Brown EP, Ackerman ME. The role of Fc receptors in HIV prevention and therapy. Immunol Rev (2015) 268:296-310. doi:10.1111/ imr.12339

37. Nagelkerke SQ, Kuijpers TW. Immunomodulation by IVIg and the role of Fc-gamma receptors: classic mechanisms of action after all? Front Immunol (2014) 5:674. doi:10.3389/fimmu.2014.00674. eCollection 2014.

38. Vidarsson G, Dekkers G, Rispens T. IgG subclasses and allotypes: from structure to effector functions. Front Immunol (2014) 5:520. doi:10.3389/ fimmu.2014.00520

39. Bruhns P, Iannascoli B, England P, Mancardi DA, Fernandez N, Jorieux S, et al. Specificity and affinity of human Fcgamma receptors and their polymorphic variants for human IgG subclasses. Blood (2009) 113:3716-25. doi:10.1182/blood-2008-09-179754

40. Forthal DN, Landucci G, Bream J, Jacobson LP, Phan TB, Montoya B. FcgammaRIIa genotype predicts progression of HIV infection. J Immunol (2007) 179:7916-23. doi:10.4049/jimmunol.179.11.7916

41. Li SS, Gilbert PB, Tomaras GD, Kijak G, Ferrari G, Thomas R, et al. FCGR2C polymorphisms associate with HIV-1 vaccine protection in RV144 trial. J Clin Invest (2014) 124:3879-90. doi:10.1172/JCI75539

42. Deepe GS Jr, Buesing WR. Deciphering the pathways of death of Histoplasma capsulatum-infected macrophages: implications for the immunopathogenesis of early infection. J Immunol (2012) 188:334-44. doi:10.4049/ jimmunol.1102175

43. Tuero I, Mohanram V, Musich T, Miller L, Vargas-Inchaustegui DA, Demberg T, et al. Mucosal B cells are associated with delayed SIV acquisition in vaccinated female but not male rhesus macaques following SIVmac251 rectal challenge. PLoS Pathog (2015) 11:e1005101. doi:10.1371/journal. ppat.1005101

44. Barouch DH, Alter G, Broge T, Linde C, Ackerman ME, Brown EP, et al. Protective efficacy of adenovirus/protein vaccines against SIV challenges in rhesus monkeys. Science (2015) 349:320-4. doi:10.1126/science.aab3886

45. Barouch DH, Stephenson KE, Borducchi EN, Smith K, Stanley K, McNally AG, et al. Protective efficacy of a global HIV-1 mosaic vaccine against heterologous SHIV challenges in rhesus monkeys. Cell (2013) 155:531-9. doi:10.1016/j.cell.2013.09.061

46. Sips M, Krykbaeva M, Diefenbach TJ, Ghebremichael M, Bowman BA, Dugast AS, et al. Fc receptor-mediated phagocytosis in tissues as a potent mechanism for preventive and therapeutic HIV vaccine strategies. Mucosal Immunol (2016) 9:1584-95. doi:10.1038/mi.2016.12

47. Ackerman ME, Dugast AS, McAndrew EG, Tsoukas S, Licht AF, Irvine DJ, et al. Enhanced phagocytic activity of HIV-specific antibodies correlates with natural production of immunoglobulins with skewed affinity for FcgammaR2a and FcgammaR2b. J Virol (2013) 87:5468-76. doi:10.1128/ JVI.03403-12

48. Abes R, Gelize E, Fridman WH, Teillaud JL. Long-lasting antitumor protection by anti-CD20 antibody through cellular immune response. Blood (2010) 116:926-34. doi:10.1182/blood-2009-10-248609

49. Michaud HA, Eliaou JF, Lafont V, Bonnefoy N, Gros L. Tumor antigen-targeting monoclonal antibody-based immunotherapy: orchestrating combined strategies for the development of long-term antitumor immunity. Oncoimmunology (2014) 3:e955684. doi:10.4161/21624011.2014.955684

50. Nimmerjahn F, Ravetch JV. Antibody-mediated modulation of immune responses. Immunol Rev (2010) 236:265-75. doi:10.1111/j.1600-065X. 2010.00910.x

51. Regnault A, Lankar D, Lacabanne V, Rodriguez A, Thery C, Rescigno M, et al. Fcgamma receptor-mediated induction of dendritic cell maturation and major histocompatibility complex class I-restricted antigen presentation after immune complex internalization. J Exp Med (1999) 189:371-80. doi:10.1084/jem.189.2.371

52. Su B, Peressin M, Ducloy C, Penichon J, Mayr LM, Laumond G, et al. Short communication: exploring antibody potential as prophylactic/therapeutic strategies for prevention of early mucosal HIV-1 infection. AIDS Res Hum Retroviruses (2015) 31:1187-91. doi:10.1089/AID.2015.0041

53. Su B, Lederle A, Laumond G, Ducloy C, Schmidt S, Decoville T, et al. Broadly neutralizing antibody VRC01 prevents HIV-1 transmission from plasmacytoid dendritic cells to CD4 T lymphocytes. J Virol (2014) 88:10975-81. doi:10.1128/JVI.01748-14

54. Su B, Xu K, Lederle A, Peressin M, Biedma ME, Laumond G, et al. Neutralizing antibodies inhibit HIV-1 transfer from primary dendritic cells to autologous CD4 T lymphocytes. Blood (2012) 120:3708-17. doi:10.1182/ blood-2012-03-418913

55. Barouch DH, Whitney JB, Moldt B, Klein F, Oliveira TY, Liu J, et al. Therapeutic efficacy of potent neutralizing HIV-1-specific monoclonal antibodies in SHIV-infected rhesus monkeys. Nature (2013) 503:224-8. doi:10.1038/nature12744

56. Ng CT, Jaworski JP, Jayaraman P, Sutton WF, Delio P, Kuller L, et al. Passive neutralizing antibody controls SHIV viremia and enhances B cell responses in infant macaques. Nat Med (2010) 16:1117-9. doi:10.1038/nm.2233

57. Watkins JD, Siddappa NB, Lakhashe SK, Humbert M, Sholukh A, Hemashettar G, et al. An anti-HIV-1 V3 loop antibody fully protects cross-clade and elicits T-cell immunity in macaques mucosally challenged with an R5 clade C SHIV. PLoS One (2011) 6:e18207. doi:10.1371/journal. pone.0018207

58. Schoofs $T$, Klein F, Braunschweig $M$, Kreider EF, Feldmann A, Nogueira L, et al. HIV-1 therapy with monoclonal antibody 3BNC117 elicits host immune responses against HIV-1. Science (2016) 352:997-1001. doi:10.1126/science.aaf0972

59. Law KM, Satija N, Esposito AM, Chen BK. Cell-to-cell spread of HIV and viral pathogenesis. Adv Virus Res (2016) 95:43-85. doi:10.1016/ bs.aivir.2016.03.001

60. Casartelli N. HIV-1 cell-to-cell transmission and antiviral strategies: an overview. Curr Drug Targets (2016) 17:65-75. doi:10.2174/1389450117011 51217105638 
61. Agosto LM, Uchil PD, Mothes W. HIV cell-to-cell transmission: effects on pathogenesis and antiretroviral therapy. Trends Microbiol (2015) 23:289-95. doi:10.1016/j.tim.2015.02.003

62. Li H, Zony C, Chen P, Chen BK. Reduced potency and incomplete neutralization of broadly neutralizing antibodies against cell-to-cell transmission of HIV-1 with transmitted founder Envs. J Virol (2017) 91:e2425-2416. doi:10.1128/JVI.02425-16

63. Gombos RB, Kolodkin-Gal D, Eslamizar L, Owuor JO, Mazzola E, Gonzalez AM, et al. Inhibitory effect of individual or combinations of broadly neutralizing antibodies and antiviral reagents against cell-free and cell-to-cell HIV-1 transmission. J Virol (2015) 89:7813-28. doi:10.1128/JVI. 00783-15

64. Zhong P, Agosto LM, Ilinskaya A, Doribal B, Truong R, Derse D, et al. Cell-tocell transmission can overcome multiple donor and target cell barriers imposed on cell-free HIV. PLoS One (2013) 8:e53138. doi:10.1371/journal.pone.0053138

65. Malbec M, Porrot F, Rua R, Horwitz J, Klein F, Halper-Stromberg A, et al. Broadly neutralizing antibodies that inhibit HIV-1 cell to cell transmission. J Exp Med (2013) 210:2813-21. doi:10.1084/jem.20131244

66. Sagar M, Akiyama H, Etemad B, Ramirez N, Freitas I, Gummuluru S. Transmembrane domain membrane proximal external region but not surface unit-directed broadly neutralizing HIV-1 antibodies can restrict dendritic cell-mediated HIV-1 trans-infection. J Infect Dis (2012) 205:1248-57. doi:10.1093/infdis/jis183

67. Durham ND, Yewdall AW, Chen P, Lee R, Zony C, Robinson JE, et al. Neutralization resistance of virological synapse-mediated HIV-1 infection is regulated by the gp41 cytoplasmic tail. J Virol (2012) 86:7484-95. doi:10.1128/JVI.00230-12

68. Abela IA, Berlinger L, Schanz M, Reynell L, Gunthard HF, Rusert P, et al. Cell-cell transmission enables HIV-1 to evade inhibition by potent CD4bs directed antibodies. PLoS Pathog (2012) 8:e1002634. doi:10.1371/journal. ppat. 1002634

69. Sanchez-Palomino S, Massanella M, Carrillo J, Garcia A, Garcia F, Gonzalez N, et al. A cell-to-cell HIV transfer assay identifies humoral responses with broad neutralization activity. Vaccine (2011) 29:5250-9. doi:10.1016/j.vaccine.2011.05.016

70. Dale BM, McNerney GP, Thompson DL, Hubner W, de Los Reyes K, Chuang FY, et al. Cell-to-cell transfer of HIV-1 via virological synapses leads to endosomal virion maturation that activates Viral membrane fusion. Cell Host Microbe (2011) 10:551-62. doi:10.1016/j.chom.2011.10.015

71. Hubner W, McNerney GP, Chen P, Dale BM, Gordon RE, Chuang FY, et al. Quantitative 3D video microscopy of HIV transfer across T cell virological synapses. Science (2009) 323:1743-7. doi:10.1126/science.1167525

72. Chen P, Hubner W, Spinelli MA, Chen BK. Predominant mode of human immunodeficiency virus transfer between $\mathrm{T}$ cells is mediated by sustained Env-dependent neutralization-resistant virological synapses. J Virol (2007) 81:12582-95. doi:10.1128/JVI.00381-07

73. Martin N, Welsch S, Jolly C, Briggs JA, Vaux D, Sattentau QJ. Virological synapse-mediated spread of human immunodeficiency virus type 1 between T cells is sensitive to entry inhibition. J Virol (2010) 84:3516-27. doi:10.1128/ JVI.02651-09

74. Duncan CJ, Williams JP, Schiffner T, Gartner K, Ochsenbauer C, Kappes J, et al. High-multiplicity HIV-1 infection and neutralizing antibody evasion mediated by the macrophage-T cell virological synapse. JVirol (2014) 88:2025-34. doi:10.1128/JVI.03245-13

75. Duncan CJ, Russell RA, Sattentau QJ. High multiplicity HIV-1 cell-to-cell transmission from macrophages to $\mathrm{CD} 4+\mathrm{T}$ cells limits antiretroviral efficacy. AIDS (2013) 27:2201-6. doi:10.1097/QAD.0b013e3283632ec4

76. Wilflingseder D, Banki Z, Garcia E, Pruenster M, Pfister G, Muellauer B, et al. IgG opsonization of HIV impedes provirus formation in and infection of dendritic cells and subsequent long-term transfer to T cells. J Immunol (2007) 178:7840-8. doi:10.4049/jimmunol.178.12.7840

77. Wren LH, Chung AW, Isitman G, Kelleher AD, Parsons MS, Amin J, et al. Specific antibody-dependent cellular cytotoxicity responses associated with slow progression of HIV infection. Immunology (2013) 138:116-23. doi:10.1111/imm.12016

78. Chung AW, Navis M, Isitman G, Centre R, Finlayson R, Bloch M, et al. Activation of NK cells by ADCC responses during early HIV infection. Viral Immunol (2011) 24:171-5. doi:10.1089/vim.2010.0108
79. Baum LL, Cassutt KJ, Knigge K, Khattri R, Margolick J, Rinaldo C, et al. HIV-1 gp120-specific antibody-dependent cell-mediated cytotoxicity correlates with rate of disease progression. JImmunol (1996) 157: 2168-73.

80. Chung AW, Ghebremichael M, Robinson H, Brown E, Choi I, Lane S, et al. Polyfunctional Fc-effector profiles mediated by IgG subclass selection distinguish RV144 and VAX003 vaccines. Sci Transl Med (2014) 6:228ra238. doi:10.1126/scitranslmed.3007736

81. Mayr LM, Decoville T, Schmidt S, Laumond G, Klingler J, Ducloy C, et al. Non-neutralizing antibodies targeting the V1V2 domain of HIV exhibit strong antibody-dependent cell-mediated cytotoxic activity. Sci Rep (2017) 7:12655. doi:10.1038/s41598-017-12883-6

82. Lewis GK. The first $24 \mathrm{~h}$ : targeting the window of opportunity for antibody-mediated protection against HIV-1 transmission. Curr Opin HIV AIDS (2016) 11:561-8. doi:10.1097/COH.0000000000000319

83. Veillette M, Richard J, Pazgier M, Lewis GK, Parsons MS, Finzi A. Role of HIV-1 envelope glycoproteins conformation and accessory proteins on ADCC responses. Curr HIV Res (2016) 14:9-23. doi:10.2174/15701 62X13666150827093449

84. Gohain N, Tolbert WD, Orlandi C, Richard J, Ding S, Chen X, et al. Molecular basis for epitope recognition by non-neutralizing anti-gp41 antibody F240. Sci Rep (2016) 6:36685. doi:10.1038/srep36685

85. Descours B, Petitjean G, Lopez-Zaragoza JL, Bruel T, Raffel R, Psomas C, et al. CD32a is a marker of a CD4 T-cell HIV reservoir harbouring replication-competent proviruses. Nature (2017) 543:564-7. doi:10.1038/ nature 21710

86. Hirvinen M, Heiskanen R, Oksanen M, Pesonen S, Liikanen I, Joensuu T, et al. Fc-gamma receptor polymorphisms as predictive and prognostic factors in patients receiving oncolytic adenovirus treatment. J Transl Med (2013) 11:193. doi:10.1186/1479-5876-11-193

87. Killick J, Morisse G, Sieger D, Astier AL. Complement as a regulator of adaptive immunity. Semin Immunopathol (2017):1-12. doi:10.1007/ s00281-017-0644-y

88. Ghebrehiwet B. The complement system: an evolution in progress. F1000Res (2016) 5:2840. doi:10.12688/f1000research.10065.1

89. Nesargikar PN, Spiller B, Chavez R. The complement system: history, pathways, cascade and inhibitors. Eur J Microbiol Immunol (Bp) (2012) 2:103-11. doi:10.1556/EuJMI.2.2012.2.2

90. Carroll MC. The complement system in regulation of adaptive immunity. Nat Immunol (2004) 5:981-6. doi:10.1038/ni1113

91. Freeley S, Kemper C, Le Friec G. The "ins and outs" of complement-driven immune responses. Immunol Rev (2016) 274:16-32. doi:10.1111/imr.12472

92. Susal C, Kirschfink M, Kropelin M, Daniel V, Opelz G. Complement activation by recombinant HIV-1 glycoprotein gp120. J Immunol (1994) 152:6028-34.

93. Solder BM, Schulz TF, Hengster P, Lower J, Larcher C, Bitterlich G, et al. HIV and HIV-infected cells differentially activate the human complement system independent of antibody. Immunol Lett (1989) 22:135-45. doi:10.1016/0165-2478(89)90180-6

94. Frank MM, Hester C, Jiang H. Complement and the control of HIV infection: an evolving story. Curr Opin HIV AIDS (2014) 9:278-90. doi:10.1097/ COH.0000000000000058

95. Yu Q, Yu R, Qin X. The good and evil of complement activation in HIV-1 infection. Cell Mol Immunol (2010) 7:334-40. doi:10.1038/cmi.2010.8

96. Stoiber H, Pruenster M, Ammann CG, Dierich MP. Complement-opsonized HIV: the free rider on its way to infection. Mol Immunol (2005) 42:153-60. doi:10.1016/j.molimm.2004.06.024

97. Montefiori DC, Cornell RJ, Zhou JY, Zhou JT, Hirsch VM, Johnson PR. Complement control proteins, CD46, CD55, and CD59, as common surface constituents of human and simian immunodeficiency viruses and possible targets for vaccine protection. Virology (1994) 205:82-92. doi:10.1006/ viro.1994.1622

98. Willey S, Aasa-Chapman MM, O’Farrell S, Pellegrino P, Williams I, Weiss RA, et al. Extensive complement-dependent enhancement of HIV-1 by autologous non-neutralising antibodies at early stages of infection. Retrovirology (2011) 8:16. doi:10.1186/1742-4690-8-16

99. Montefiori DC, Pantaleo G, Fink LM, Zhou JT, Zhou JY, Bilska M, et al. Neutralizing and infection-enhancing antibody responses to human 
immunodeficiency virus type 1 in long-term nonprogressors. J Infect Dis (1996) 173:60-7. doi:10.1093/infdis/173.1.60

100. Fust G, Toth FD, Kiss J, Ujhelyi E, Nagy I, Banhegyi D. Neutralizing and enhancing antibodies measured in complement-restored serum samples from HIV-1-infected individuals correlate with immunosuppression and disease. AIDS (1994) 8:603-9. doi:10.1097/00002030-199405000-00005

101. Banki Z, Stoiber H, Dierich MP. HIV and human complement: inefficient virolysis and effective adherence. Immunol Lett (2005) 97:209-14. doi:10.1016/j.imlet.2004.11.007

102. Robinson WE Jr, Montefiori DC, Mitchell WM. Complement-mediated antibody-dependent enhancement of HIV-1 infection requires CD4 and complementreceptors. Virology (1990) 175:600-4.doi:10.1016/0042-6822(90)90449-2

103. Robinson WE Jr, Montefiori DC, Gillespie DH, Mitchell WM. Complementmediated, antibody-dependent enhancement of HIV-1 infection in vitro is characterized by increased protein and RNA syntheses and infectious virus release. J Acquir Immune Defic Syndr (1989) 2:33-42.

104. Robinson WE Jr, Montefiori DC, Mitchell WM. Antibody-dependent enhancement of human immunodeficiency virus type 1 infection. Lancet (1988) 1:790-4. doi:10.1016/S0140-6736(88)91657-1
105. Perez LG, Martinez DR, deCamp AC, Pinter A, Berman PW, Francis D, et al. V1V2-specific complement activating serum IgG as a correlate of reduced HIV-1 infection risk in RV144. PLoS One (2017) 12:e0180720. doi:10.1371/journal.pone. 0180720

106. Rouers A, Klingler J, Su B, Samri A, Laumond G, Even S, et al. HIV-specific $B$ cell frequency correlates with neutralization breadth in patients naturally controlling HIV-infection. EBioMedicine (2017) 21:158-69. doi:10.1016/j. ebiom.2017.05.029

Conflict of Interest Statement: The authors declare that the research was conducted in the absence of any commercial or financial relationships that could be construed as a potential conflict of interest.

Copyright (๑) 2017 Mayr, Su and Moog. This is an open-access article distributed under the terms of the Creative Commons Attribution License (CC BY). The use, distribution or reproduction in other forums is permitted, provided the original author(s) or licensor are credited and that the original publication in this journal is cited, in accordance with accepted academic practice. No use, distribution or reproduction is permitted which does not comply with these terms. 